\title{
High-resolution SNP array analysis of patients with developmental disorder and normal array CGH results
}

\author{
Linda Siggberg ${ }^{1 *}$, Ala-Mello Sirpa ${ }^{2}$, Linnankivi Tarja ${ }^{3}$, Avela Kristiina ${ }^{4}$, Scheinin Ilari ${ }^{1,5,7}$, Kristiansson Kati ${ }^{6,7}$, \\ Lahermo Päivi ${ }^{7}$, Hietala Marja ${ }^{8}$, Metsähonkala Liisa ${ }^{3}$, Kuusinen Esa ${ }^{9}$, Laaksonen Maarit ${ }^{10}$, Saarela Janna ${ }^{7}$ \\ and Knuutila Sakari ${ }^{1}$
}

\begin{abstract}
Background: Diagnostic analysis of patients with developmental disorders has improved over recent years largely due to the use of microarray technology. Array methods that facilitate copy number analysis have enabled the diagnosis of up to $20 \%$ more patients with previously normal karyotyping results. A substantial number of patients remain undiagnosed, however.

Methods and Results: Using the Genome-Wide Human SNP array 6.0, we analyzed 35 patients with a developmental disorder of unknown cause and normal array comparative genomic hybridization (array CGH) results, in order to characterize previously undefined genomic aberrations. We detected no seemingly pathogenic copy number aberrations. Most of the vast amount of data produced by the array was polymorphic and non-informative. Filtering of this data, based on copy number variant (CNV) population frequencies as well as phenotypically relevant genes, enabled pinpointing regions of allelic homozygosity that included candidate genes correlating to the phenotypic features in four patients, but results could not be confirmed.

Conclusions: In this study, the use of an ultra high-resolution SNP array did not contribute to further diagnose patients with developmental disorders of unknown cause. The statistical power of these results is limited by the small size of the patient cohort, and interpretation of these negative results can only be applied to the patients studied here. We present the results of our study and the recurrence of clustered allelic homozygosity present in this material, as detected by the SNP 6.0 array.
\end{abstract}

Keywords: Developmental disorder, SNP array, Diagnostic yield

\section{Background}

The diagnostic yield of microarray comparative genomic hybridizations (array CGH) has already proven to exceed that of cytogenetic methods, except when it comes to balanced rearrangements. A consensus statement suggests that microarrays should be used as the first line of testing for developmental disorders of unknown cause [1]. However, as our previous study shows, approximately $80 \%$ of patients with a developmental disorder of unknown cause (mental retardation and/or malformations

\footnotetext{
* Correspondence: linda.siggberg@helsinki.fi

'Department of Pathology, Haartman Institute, University of Helsinki, and Laboratory of Helsinki and Uusimaa University Hospital, Helsinki, Finland Full list of author information is available at the end of the article
}

and/or neurological disorders) remain undiagnosed even by array CGH analysis (44 K, $180 \mathrm{~K}$, or $244 \mathrm{~K})$ [2]. Thus, other methods are clearly needed to define the pathogenic mechanisms. It is plausible that small copy number variants (CNVs) may go undetected if the probe coverage is limited, as it may be in low-resolution arrays. By increasing the resolution, one would thus expect to detect increasingly smaller pathogenic CNVs.

The frequency of uniparental disomy (UPD) in newborns is reportedly $\sim 0.029 \%$ [3]. Around 1,100 cases of whole chromosome UPD and some 120 reports on segmental UPD are described in the literature [4]. Some recessive diseases are expressed in children who have inherited the mutation form a single carrier

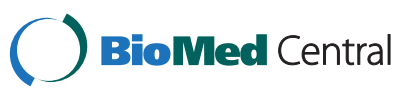


parent [5]. The explanation for this is a meiotic or very early mitotic recombination event between parental homologous chromosomes causing segmental UPD of the genomic segment containing the mutation, and thereby causing a reduction to homozygosity.

As the market is flooded with new arrays, most having an increased resolution and a promise of ever higher detection rates, the question remains what the added value is of these ultra-high resolution arrays. To test this, we used an array with 1.8 million probes and an average resolution of $0.7 \mathrm{~Kb}$ to analyze samples of 35 patients with developmental disorder of unknown cause, normal karyotype, and normal array CGH results by use of Agilent $44 \mathrm{~K}, 180 \mathrm{~K}$, or $244 \mathrm{~K}$ platforms (Agilent Technologies, Santa Clara, CA, USA).

\section{Methods}

\section{Participants}

Patients with previous normal array CGH results were asked to participate in the project. All 35 patients were Finnish of origin and had mild to severe mental retardation, associated with dysmorphic features and/or congenital anomalies (Table 1). In addition, 16 patients also had epilepsy. For diagnostic purposes patients had previously been analyzed by whole-genome array CGH (Human Genome CGH Microarray, Agilent Technologies, Santa Clara, CA); 20 using the $244 \mathrm{~K}$ platform, 8 using a $180 \mathrm{~K}$ platform, and 7 using a $44 \mathrm{~K}$ platform. Informed consent was given by all participating families. Blood samples were collected from all patients and their parents. Ethical permission for this project was given by the Ethics Review Board of Helsinki and Uusimaa Hospital District.

\section{SNP array}

DNA was extracted from blood samples according to standard protocols. Analysis by the Genome-wide human SNP array 6.0 was performed according to manufacturer protocols (Affymetrix, Santa Clara, CA, USA). In short; DNA was digested, ligated to adapters, and amplified by PCR. Samples were purified using magnetic beads and further fragmented and labelled with biotin. After hybridization arrays were washed and stained with streptavidin and anti-streptavidin antibodies and finally the arrays were scanned using the Affymetrix GeneChip scanner.

\section{Analysis}

Data was extracted from the scanned image using the Genotyping console software V.3.0.2, creating a CEL file. Areas containing $\mathrm{CNVs}$ and allelic homozygosity were detected using the Hidden-Markow-Model. The resulting data was analyzed using the Chromosome Analysis Suite software V.1.0.

\section{Reference data}

Data was extracted by comparison to a reference data set established from 90 Caucasian individuals, which had previously been analyzed using the SNP 6.0 array in the HapMap project (www.hapmap.org). As an additional in-house reference set, we used results of 54 individuals studied using the SNP 6.0 array, whereof 19 healthy normal relatives of the patients, and 35 unrelated patients with an unexplained developmental disorder. Sample identities were kept anonymous and the information was only used for reference purposes. These in-house reference sets were used to filter out polymorphic changes in the patient data studied here.

Selected CNVs of the patients were compared to a Finnish population cohort [6]. This population cohort data consist of CNVs detected, using whole-genome SNP analysis, in 2163 healthy Finnish individuals with PennCNV [7]. In the population data, low quality samples $(\mathrm{N}=98)$ with $\log \mathrm{R}$ Ratio standard deviation of probe signal intensities $>0.35$ or $>115 \mathrm{CNV}$ calls were excluded. Only CNVs with three or more probes were included in the final population data. CNV calls of the study samples were clustered into CNV regions when individual CNVs overlapped by one or more base pairs.

\section{Filtering relevant CNVs and potential UPDs}

The first set of default filtering marked all duplications and deletions $\geq 0.7 \mathrm{~Kb}$ and all allelic homozygosities $\geq 100 \mathrm{~Kb}$ containing at least 10 markers to be included. This was based on the theoretical resolution of the array being $0.7 \mathrm{~Kb}$, in addition to information from the HapMap phase 1 study showing that approximately $70 \%$ of common haplotype blocks are $\leq 100 \mathrm{~Kb}$ [8]. Allelic homozygosity was called by the analysis software where there was a stretch of homozygous SNPs in a chromosomal segment.

The second filtering was based on the comparison of all aberrations detected in the patients of this study $(\mathrm{N}=35)$, an in-house patient reference set $(\mathrm{N}=35)$ and an in-house normal reference set $(\mathrm{N}=19)$ as well as the database of genomic variants (DGV) [9]. Aberrations of one patient that were not present in any of the other groups (potentially "unique") were further processed by studying their genetic content and association to diseases and traits, as stated in publications or OMIM, and whether these correlated to the patient's phenotype. If this did not yield a candidate aberration, all aberrations of a patient were reviewed based on only the associated OMIM disease, despite the frequency of similar changes in the reference sets. The CNVs that were picked out as potential candidates were further compared to $\mathrm{CNV}$ data 
Table 1 Clinical characteristics of patients studied

\begin{tabular}{lll}
\hline P. Nr. Growth & $\begin{array}{l}\text { Head and } \\
\text { neck }\end{array}$ & Eyes and visio \\
\hline $1 . \quad$ Obesity & & \\
& & \\
2 & \\
& \\
3. & \\
& $\begin{array}{l}\text { Doligmatism } \\
\text { Narrow, } \\
\text { prominent } \\
\text { forehead Low, } \\
\text { uneven } \\
\text { hairline }\end{array}$ \\
&
\end{tabular}

4. Short stature

Low nasal bridge

Thick and straight eyebrows Broad nasal bridge Long philtrum Retrognathia

Small nose Low nasal bridge

Tented upper lip

Severe optic

atrophy Impaired

vision

Mild hypertelorism Low-set ears

\section{Triangular face}

Small jaw High

palate Thin upper

lip

11.
Upslanting Large Small jaw

palpebal earlobes

fissures

Epichantic folds Flat face
Cardiovascular Genitourinary

\begin{tabular}{l} 
Skeletal and \\
limb defects \\
\hline Postaxial \\
polydactyly \\
(one foot) Short \\
meta-carpals \\
$V$ finger \\
clino-dactyly
\end{tabular}

Neurologic

Other

ID Hypotonia

Bardet-Biedl

suspected

clino-dactyly

Severe DD

No walk/craw

No speech

Epilepsy Drooling

DD Abnormal Hemangiomas

pons

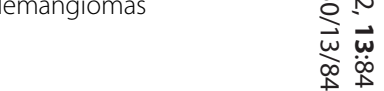

Horseshoe

kidney Ana

Small hands

ID

and feet

Balanced $t(X ; 13)$

atresia

Autism ID Epilepsy

(q28;q12)

Scoliosis

ID Epilepsy Severe

hypotonia

Brain malformation

Severe DD

Severe DD

Severe epilepsy

ATRX suspected

ID Epilepsy Cortical

atrophy

Hyper-extensible ID Autistic features

joints Intractable epilepsy

Frax-dna, SCN1A,

CLN8 4p-FISH

normal

Clubfoot ID Autistic features

Intractable epilepsy

Tapering fingers 
Table 1 Clinical characteristics of patients studied (Continued)

\begin{tabular}{|c|c|c|c|c|c|c|c|c|c|c|}
\hline & & & & $\begin{array}{l}\text { Large } \\
\text { earlobes }\end{array}$ & & & & & $\begin{array}{l}\text { ID Autistic features } \\
\text { ADHD }\end{array}$ & $\begin{array}{l}\text { Balanced } \mathrm{t}(2 ; 9) \\
\text { (q13q22.3) } \\
\text { de novo }\end{array}$ \\
\hline 13. & & Macrocephaly & & & & & & & $\begin{array}{l}\text { Severe ID Hypotonia } \\
\text { Autism Epilepsy }\end{array}$ & $\begin{array}{l}\text { Inv 2(p13p25) } \\
\text { mat., DMPK } \\
\text { mutation } \\
\text { negative }\end{array}$ \\
\hline 14. & & & $\begin{array}{l}\text { Severe myopia } \\
\text { Cataracta }\end{array}$ & & $\begin{array}{l}\text { Synophrys Curved } \\
\text { eyebrows } \\
\text { Upturned } \\
\text { pinched nose Big } \\
\text { mouth Full lips }\end{array}$ & $\begin{array}{l}\text { Atrial septum } \\
\text { defect }\end{array}$ & & & Severe DD Epilepsy & \\
\hline 15. & & Microcephaly & Impaired vision & & & $\begin{array}{l}\text { Ventricular } \\
\text { septum defect }\end{array}$ & & & Epilepsy DD & \\
\hline 16. & & & & & & & & & $\begin{array}{l}\text { ID Beahvioural } \\
\text { disturbances Autism }\end{array}$ & $\begin{array}{l}\text { No malformation } \\
\text { or dysmorphism }\end{array}$ \\
\hline 17. & & & & & & & & & ID DD & \\
\hline 18. & $\begin{array}{l}\text { Growth } \\
\text { retardation }\end{array}$ & & Hypertelorism & & & $\begin{array}{l}\text { Mild ventricular } \\
\text { septum defect }\end{array}$ & & & ID & \\
\hline $\begin{array}{l}19 . \\
20 .\end{array}$ & \& & & & & & & & & DD & $\begin{array}{l}\text { No structural } \\
\text { defects }\end{array}$ \\
\hline 21 & & Microcephaly & Strabismus & Missing lobuli & $\begin{array}{l}\text { Small nose Low } \\
\text { nasal bridge } \\
\text { Smooth philtrum } \\
\text { Thin lips }\end{array}$ & & & $\begin{array}{l}\text { Proximal } \\
\text { thumbs } \\
\text { Pes planus }\end{array}$ & $\begin{array}{l}\text { ID Intractable } \\
\text { epilepsy Ataxia }\end{array}$ & \\
\hline 22. & $\begin{array}{l}\text { Pre- and postnatal } \\
\text { growth retardation }\end{array}$ & & & & $\begin{array}{l}\text { Broad nasal root } \\
\text { Short nose Bifid } \\
\text { nasal tip }\end{array}$ & & $\begin{array}{l}\text { Cryptorchidism } \\
\text { Hypoplastic } \\
\text { scrotum }\end{array}$ & $\begin{array}{l}\text { Scoliosis } \\
\text { Syndactylies }\end{array}$ & $\begin{array}{l}\text { Slow motor } \\
\text { development } \\
\text { Hypotonia Expressive } \\
\text { language disorder }\end{array}$ & $\begin{array}{l}\text { Congenital } \\
\text { contractures } \\
\text { Dimples }\end{array}$ \\
\hline 23. & & & & & Mild dysmorphism & & & & ID Epilepsy & \\
\hline 24. & & Microcephaly & $\begin{array}{l}\text { Hypertelorism } \\
\text { Epicanthic folds } \\
\text { Disorder of } \\
\text { visual cortex }\end{array}$ & $\begin{array}{l}\text { Low-set and } \\
\text { posteriorly } \\
\text { rotated ears }\end{array}$ & $\begin{array}{l}\text { Micrognathia Cleft } \\
\text { palate }\end{array}$ & & & & $\begin{array}{l}\text { ID Epilepsy } \\
\text { Hypoplastic } \\
\text { cerebellar } \\
\text { vermis }\end{array}$ & $\begin{array}{l}\text { Monozygotic } \\
\text { twin, twin } \\
\text { sister healthy }\end{array}$ \\
\hline 25. & $\begin{array}{l}\text { Tall stature } \\
\text { Advanced bone } \\
\text { age }\end{array}$ & & $\begin{array}{l}\text { Deep set eyes } \\
\text { Hypotelorism } \\
\text { Epicanthic folds } \\
\text { Strabismus }\end{array}$ & & $\begin{array}{l}\text { Short nose } \\
\text { Anteverted nares } \\
\text { Tented upper lip }\end{array}$ & & Cryptorchidism & & $\begin{array}{l}\text { ID No speech } \\
\text { Autism }\end{array}$ & $\begin{array}{l}\text { Glypican-3 and } \\
\text { PHF6 mutation } \\
\text { analyses negative }\end{array}$ \\
\hline 26. & Short stature & & & & & & & & $\begin{array}{l}\text { ID Intractable } \\
\text { epilepsy Tremor } \\
\text { Myoclonias Distal } \\
\text { spasticity }\end{array}$ & \\
\hline
\end{tabular}


Table 1 Clinical characteristics of patients studied (Continued)

\begin{tabular}{|c|c|c|c|c|c|c|c|c|c|c|}
\hline 27. & $\begin{array}{l}\text { Small for } \\
\text { Gestational Age }\end{array}$ & & $\begin{array}{l}\text { Downslanting } \\
\text { palpebral fissures } \\
\text { Strabismus }\end{array}$ & & Frontal bossing & & & $\begin{array}{l}\text { Exostosis } \\
\text { (familial) } \\
\text { Broad hallux } \\
\text { Overriding toes } \\
\text { Scoliosis }\end{array}$ & ID Epilepsy & Inguinal hernia \\
\hline 28. & & & $\begin{array}{l}\text { Downslanting } \\
\text { palpebral fissures }\end{array}$ & $\begin{array}{l}\text { Hearing } \\
\text { impairment }\end{array}$ & $\begin{array}{l}\text { Coarse hair Thick } \\
\text { eyebrows Thick } \\
\text { lips Malposition } \\
\text { of teeth }\end{array}$ & $\begin{array}{l}\text { Hypertrophic } \\
\text { cardiomyopathy }\end{array}$ & & $\begin{array}{l}\text { Hip } \\
\text { dis-placement } \\
\text { Long thin bones }\end{array}$ & $\begin{array}{l}\text { Normal } \\
\text { intelligence }\end{array}$ & \\
\hline 29. & & & & & & & & & $\begin{array}{l}\text { Epilepsy ID } \\
\text { Alternating } \\
\text { hemiplegia } \\
\text { of childhood }\end{array}$ & \\
\hline 30. & $\begin{array}{l}\text { Small for } \\
\text { gestational age } \\
\text { Prematurity Short } \\
\text { stature }\end{array}$ & Microcephaly & $\begin{array}{l}\text { Severe myopia } \\
\text { Coloboma of } \\
\text { papillae Optic } \\
\text { atrophy } \\
\text { Nystagmus } \\
\text { Strabismus }\end{array}$ & & $\begin{array}{l}\text { High palate } \\
\text { Gum hypertrophy }\end{array}$ & $\begin{array}{l}\text { Coarctation of } \\
\text { aorta }\end{array}$ & Inguinal hernia & & $\begin{array}{l}\text { ID Intractable } \\
\text { epilepsy Hemiparesis } \\
\text { (peri-ventricular } \\
\text { leukomalacia) }\end{array}$ & \\
\hline 31. & & & $\begin{array}{l}\text { Central blindness } \\
\text { Nystagmus }\end{array}$ & & & & & & $\begin{array}{l}\text { ID Intractable } \\
\text { epilepsy Hypotonia } \\
\text { Distal spasticity }\end{array}$ & \\
\hline 32. & Short stature & & & & & & & & $\begin{array}{l}\text { Normal } \\
\text { development }\end{array}$ & $\begin{array}{l}\text { Vomiting } \\
\text { Feeding } \\
\text { difficulties }\end{array}$ \\
\hline 33. & & Neck fistula & & & $\begin{array}{l}\text { Dysmorphic } \\
\text { malocclusion } \\
\text { of teeth }\end{array}$ & $\begin{array}{l}\text { Uni-ventricular } \\
\text { heart }\end{array}$ & & & $\begin{array}{l}\text { Brain atrophy } \\
\text { Epilepsy }\end{array}$ & $\begin{array}{l}\text { Simian-crease } \\
\text { Sinus pilonidalis }\end{array}$ \\
\hline 34. & & & & & & & & & $\begin{array}{l}\text { ID Intractable } \\
\text { epilepsy Hypotonia } \\
\text { Distal spasticity }\end{array}$ & \\
\hline 35. & & Dolicocephaly & Epichantic fold & Simple ears & $\begin{array}{l}\text { Thin upper-lip } \\
\text { Long philtrum } \\
\text { Broad nasal } \\
\text { bridge }\end{array}$ & & & & $\begin{array}{l}\text { ID Arnold Chiari } \\
\text { malformation }\end{array}$ & \\
\hline
\end{tabular}


from 2,065 healthy Finnish individuals. Only those aberrations that were present in less than 50 individuals of the Finnish population cohort were initially considered as potentially pathogenic.

\section{Validation of candidate aberrations}

Only aberrations that were considered to potentially associate with patient's phenotype were attempted validation.

\section{Microsatellite marker analysis}

Potential segmental UPDs were analyzed by microsatellite marker analysis (chr15: D15S204, D15S124; chr6: D6S468, D6S2418; chr11: D11S4140; chr17: D17S578, D17S1832, D17S1828).

The markers were selected based on their location, and on information that they are highly polymorphic in the Caucasian population. Fragments were labelled with a fluorescent HEX label, and separated on an Applied Biosystem 3730XL (Life Technologies, Carlsbad, CA,
USA) capillary electrophoresis instrument, according to manufacturer recommendations. Genotypes were called using Applied Biosystems GeneMapper 3.7 software.

\section{Results}

The immense amount of data created by the Genomewide human SNP array 6.0 warrants filtering for clear interpretation. The Genotyping Console software identified between 200-1000 changes per patient (Figure 1), depending on the technical quality of the result. More changes were detected in samples with lesser quality. After filtering, based on the uniqueness of the CNVs or regions of homozygosity compared to the references, each patient presented 8-20 unique changes $(\geq 90 \%$ CNVs) on average. In samples with lesser quality, $\geq 100$ unique changes were detected. Further research on gene content and phenotypes previously mapped to these regions revealed $23 \mathrm{CNVs}$ and 28 regions of homozygosity that putatively correlated with the clinical phenotype in 26 patients. Nine patients had no CNVs or regions of

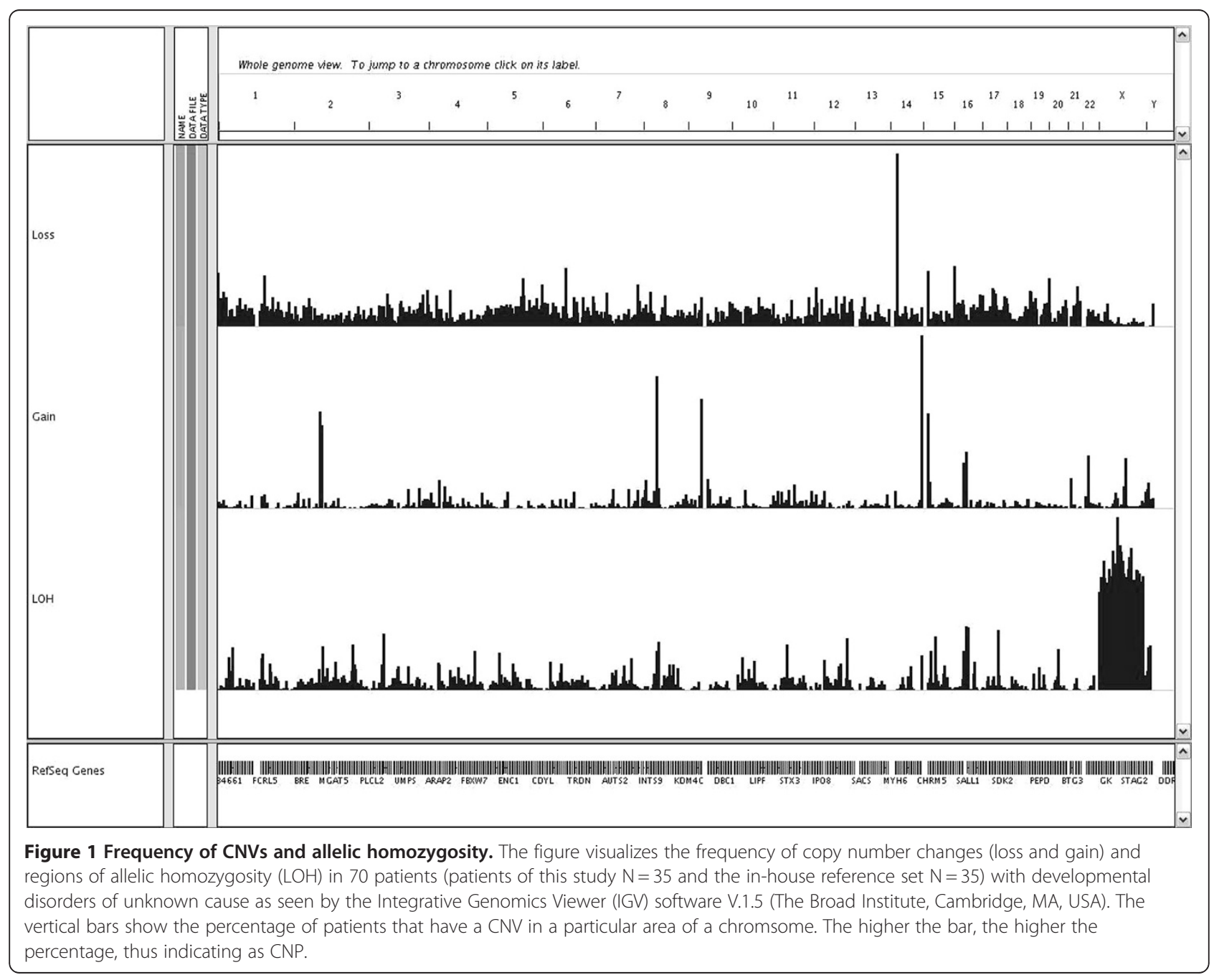


homozygosity spanning known genes or genes known to associate with a disease that correlated with the patient's phenotype, and their results were thus considered normal. The associated phenotypes related to the aberration found in 26 patients were further evaluated by the patients' clinicians, and the frequencies of the observed CNVs were monitored in the Finnish population cohort $(\mathrm{n}=2,065)$. As a result, in four patients, a region of allelic homozygosity was considered a potential candidate for causation of their clinical state (Table 2). No CNVs were considered candidates after clinical evaluation.

We further attempted verification of four potential segmental UPDs by microsatellite marker analysis. In all the four cases we observed two distinct alleles with at least some of the more informative multiallelic markers, suggesting that the observed LOHs were most probably caused by the same allelic SNP haplotypes being inherited from both the parents (Table 2).

Further comparison, of all patient SNP array data to the normal data from unaffected individuals, revealed 21 regions of clustering ( $\geq 40 \%$ frequency) of allelic homozygosity to specific locations of the genome (Table 3 ). However, no significant differences were detected between the frequencies of clustered regions in patients and the unaffected relatives in this small set of samples.

\section{Discussion}

In our previous study of 150 patients with developmental disorders of unknown cause and a normal karyotype, we were able to identify a (potential) causative aberration in $18 \%$ of the patients, by using a $44 \mathrm{~K}$ or $244 \mathrm{~K}$ array CGH platform [2].
To determine whether, by increasing the resolution, any additional copy number changes or regions of UPD could be detected, we studied 35 patients with a normal array CGH result.

Allelic homozygosity is typically caused by linkage and co-segregation of certain blocks of DNA, termed haplotypes [8]. In a small founder population, such as the Finnish population, the founder effect increases the likelihood that the parents will have the same haplotype, and is as such not a segmental UPD [10]. True segmental UPD is typically due to a duplication in one chromosome and a reciprocal deletion in the other; or the fertilization of a disomic and monosomic gamete, somatic crossing over and subsequent trisomic rescue [11]. If the genomic segment harbours a recessive mutation, which subsequent to UPD will be present in two copies (reduction to homozygosity), it causes a recessive disease. Equally relevant, the segment can be preferentially imprinted, causing complete silencing, which is the equivalent of a deletion. Such presentations of recessive syndromes that are inherited from one normal parent are known in some 40 patients [12].

We were interested to see whether the regions of allelic homozygosity detected by the SNP array were in fact segmental UPDs and associated with an autosomal recessive disease. We were, however, unable to confirm these results and thus the SNP array did not yield more molecular diagnoses in this study of developmental disorders of unknown cause. This may be due to the fact that all patients had previously been studied by another high-resolution array, with $8.9 \mathrm{~Kb}(244 \mathrm{~K}), 13 \mathrm{~Kb}(180 \mathrm{~K})$, and $35 \mathrm{~Kb}(44 \mathrm{~K})$ theoretical resolutions. Although several new CNVs, previously undetected by the array CGH

Table 2 Results from microsatellite marker analysis

\begin{tabular}{|c|c|c|c|c|c|c|c|c|}
\hline Patient & Chromosome location & Marker & Location start & Location stop & Patient & Mother & Father & $\begin{array}{l}\text { Associated OMIM } \\
\text { disease (gene) }\end{array}$ \\
\hline \multirow[t]{2}{*}{1} & $15 q 23 q 24.1$ & D15S204 & 72300758 & 72300879 & $123 / 123$ & $123 / 125$ & $123 / 125$ & $\begin{array}{l}\text { MIM \#209900, Bardet-Biedl } \\
\text { Syndrome (BBS4) }\end{array}$ \\
\hline & & D15S124 & 73092468 & 73092572 & $104 / 106$ & $106 / 106$ & 104/106 & \\
\hline \multirow[t]{2}{*}{17} & $6 q 16.3$ & D6S468 & 101630330 & 101630479 & $155 / 159$ & 159/159 & $155 / 155$ & $\begin{array}{l}\text { MIM \#611092, Mental } \\
\text { retardation (GRIK2) }\end{array}$ \\
\hline & & D6S2418 & 101352425 & 101352639 & $222 / 230$ & $222 / 248$ & $230 / 238$ & \\
\hline 32 & $11 q 13.4$ & DS11S4140 & 71945684 & 71945874 & 195/195 & 195/197 & 195/197 & $\begin{array}{l}\text { MIM \#270400, } \\
\text { Smith-Lemli-Opitz } \\
\text { syndrome (DHCR7) }\end{array}$ \\
\hline \multirow[t]{3}{*}{28} & 17p13.2p13.1 & D17S578 & 6824007 & 6824153 & $173 / 173$ & $173 / 173$ & $155 / 173$ & $\begin{array}{l}\text { MIM \#201475, AcylCoA } \\
\text { dehydrogenase deficiency } \\
\text { (ACADVL) }\end{array}$ \\
\hline & & D17S1832 & 5972677 & 5972867 & $173 / 185$ & $173 / 185$ & $171 / 173 / 185 / 193$ & \\
\hline & & D17S1828 & 3810467 & 3810673 & $220 / 220$ & $214 / 220$ & $214 / 220$ & \\
\hline
\end{tabular}

The table presents the results of microsatellite marker analysis of 4 patients and their parents, suggesting biparental inheritance of the genomic segment, and thus exclude segmental UPD. The numbers in the patient/mother/father column represent the two markers detected. In all cases, the patient has likely inherited one marker from each parent. 
Table 3 Regions of clustered allelic homozygosity

\begin{tabular}{|c|c|c|c|c|}
\hline Chromosome & Band & Appoximate range $(\mathrm{Kb})$ & Frequency patients $(n=70)$ & Frequency normals $(n=19)$ \\
\hline 1 & p33-p32.3 & $48700-53300$ & $47.7 \%$ & $47.7 \%$ \\
\hline 1 & $q 21.1-q 21.2$ & $145800-148500$ & $49 \%$ & $50 \%$ \\
\hline 2 & $\mathrm{q} 21.2-\mathrm{q} 21.3$ & $134334-136693$ & $42 \%$ & $58 \%$ \\
\hline 3 & p21.31-p21.1 & $46500-52500$ & $71 \%$ & $68 \%$ \\
\hline 4 & p15.1 & $31838-34524$ & $60 \%$ & $57 \%$ \\
\hline 8 & $\mathrm{q} 22.2$ & 99 200-101200 & $47 \%$ & $63 \%$ \\
\hline 8 & p11.21-p11.1 & $41870-43270$ & $49 \%$ & $47 \%$ \\
\hline 8 & $q 11.1-q 11.21$ & $47040-49000$ & $46 \%$ & $68 \%$ \\
\hline 10 & p11.21 & $36720-38490$ & $43 \%$ & $31 \%$ \\
\hline 10 & $\mathrm{q} 22.2-\mathrm{q} 22.2$ & $73200-76460$ & $44 \%$ & $31 \%$ \\
\hline 12 & $q 21.32-q 21.33$ & $85850-89100$ & $47 \%$ & $47 \%$ \\
\hline 12 & $q 24.11-q 24.13$ & $108600-111600$ & $55 \%$ & $68 \%$ \\
\hline 14 & $\mathrm{q} 23.3-\mathrm{q} 24.1$ & $65500-67100$ & $62 \%$ & $73 \%$ \\
\hline 15 & q12-q13.1 & $25400-27200$ & $71 \%$ & $68 \%$ \\
\hline 15 & q15.1-q21.1 & $40100-43730$ & $64 \%$ & $84 \%$ \\
\hline 15 & q23-q24.1 & $69300-71700$ & $41 \%$ & $15 \%$ \\
\hline 16 & p11.2-p11.1 & 33 394-34 550 & $62 \%$ & $68 \%$ \\
\hline 16 & $q 11.2-q 12.1$ & $45092-47450$ & $64 \%$ & $63 \%$ \\
\hline 16 & q21-q22.1 & $64850-67100$ & $48 \%$ & $57 \%$ \\
\hline 17 & q22-q23.2 & $54610-56850$ & $67 \%$ & $68 \%$ \\
\hline 20 & $q 11.22-q 11.23$ & $31910-35500$ & $68 \%$ & $42 \%$ \\
\hline
\end{tabular}

The table presents the frequency ( $>40 \%$ ) of clustered regions of allelic homozygosity in the patient cohort $(n=70$, including in-house reference) compared to the unaffected relatives $(n=19)$. Kilobase range according to Genome build 19 (NCBI 37).

platform, as well as regions of homozygosity were detected, the pathogenic relevance of these changes were considered insignificant in correlation to the patient's phenotype. It is, however, possible that changes dismissed in this study are pathogenic by means of spanning genomic segments that do not directly involve disease genes, but rather their regulatory elements.

Our results differ from previously published studies using similar research settings. Bernardini et al. (2010), using the SNP 6.0 array platform with a $75 \mathrm{~Kb}$ cut-off value for detected CNVs, reported potentially pathogenic CNVs in 6\% of patients with normal array CGH result (44 K) [13]. Mannik et al. (2010), using another SNP array with a $50 \mathrm{~Kb}$ resolution, reported a $23 \%$ detection rate in patients with a normal karyotype [14]. Bernardini et al. and Mannik et al. had higher detection rates than this study; perhaps as their first-line of array analysis was, at least partly, done by a lower-resolution method ( $35 \mathrm{~Kb}$ and $50 \mathrm{~Kb}$ respectively) compared to the first-line of detection in this study $(8,9 \mathrm{~Kb}, 13 \mathrm{~Kb}$ and $35 \mathrm{~Kb})$. Also, it is important to note that the statistical power is limited by the small size of our patient cohort, and thus results are not entirely comparable with Bernardini and Mannik's.

UPDs have not been reported in either of the above mentioned studies. However, in a study of 117 patients with a normal karyotype analysed using the $250 \mathrm{~K}$ SNP array (Affymetrix, Santa Clara, CA, USA), pathogenic CNVs were detected in 18 patients, and potentially pathogenic segmental UPDs $\geq 5 \mathrm{Mb}$ in 5 , verified by microsatellite marker analysis [15]. The presence of UPDs was also evaluated in another study of 120 patients, using a $500 \mathrm{~K} \mathrm{SNP}$ array platform [16]. In that study they were unable to verify UPD in any of 121 detected regions of homozygosity in 72 patients with developmental disorder of unknown cause. In addition, in a study of 100 patients with developmental disorder, using a $500 \mathrm{~K}$ SNP array, two patients were found to have UPD, the clinical significance of which remained unclear [17]. Thus, UPDs are detectable using SNP arrays, but their clinical significance is difficult to interpret.

\section{Conclusions}

Although there is a clear added value of high-resolution arrays in various fields of genetics, it seems that there is a limit to how much the yield can be increased by increasing the theoretical resolution of the analysis platform. Despite the fact that the SNP array has increased probe spacing compared to the $44 \mathrm{~K}, 180 \mathrm{~K}$, and $244 \mathrm{~K}$ array, and is able to detect more CNVs and regions of homozygosity, interpretation of the vast amount of data 
and pinpointing of pathogenic changes is difficult. One benefit of using a SNP based platform is the possibility to detect UPDs; however these are relatively rare findings.

This study had a limited number of patients, and so it can only be said that for this study group the optimal yield was conceived when using a resolution of approximately $9 \mathrm{~Kb}$ [2]. Increasing the resolution beyond that did not confer more diagnoses. It must be emphasized, however, that a larger patient cohort needs to be studied in order to draw final conclusions on the added value of an ultra-high resolution array compared to others. Furthermore, as several reports have shown, some pathogenic aberrations span only a few exons and for detecting such small changes the sensitivity of the SNP 6.0 platform is adequate [18]. It is, however a challenge to filter results correctly and so for diagnostic purposes the choice of platform needs to be carefully considered. Patients with developmental disorders of unknown cause and normal array results may also harbour such small genomic changes (i.e. mutations and unbalanced rearrangements) that are difficult to interpret using microarrays and would require higher resolution methods, such as whole-exome sequencing. Interestingly, a recent study suggests that $80 \%$ of patients with a developmental disorder of unknown cause and normal array results can be diagnosed using whole-exome sequencing [19]. Only the future can tell.

\section{Availability of supporting data}

The data set supporting the results of this article is available in the CanGEM repository, http://www.cangem.org/ browse.php.

\section{Competing interests}

The authors declare that they have no competing interests.

\section{Authors' contributions}

LS set up the study, performed the laboratory work and analysis and drafted the manuscript. SA-M helped set up the study and assisted in clinical evaluation of results. TL, KA, MH, LM, and EK, contacted patients and assisted in clinical evaluation of results. IS performed bioinformatics filtering of the results. KK compared CNV findings with data from the Health2000 project. PL performed the microsatellite marker analysis. ML performed analysis for the Health2000 project. JS supervised the performance of the validation studies. SK helped set up and supervise the project. All authors assisted in drafting of the manuscript.

\footnotetext{
Acknowledgements

We thank all the participating patients and their families. A thanks to Marketta Dalla Valle for her contribution of clinical information. The staff from the Genotyping Facilities at the Wellcome Trust Sanger Institute is acknowledged for genotyping of the Health 2000 study sample. This study was kindly supported by Rinnekoti Research Foundation, Medicinska Understödsföreningen Liv och Hälsa rf., and The Helsinki and Uusimaa Hospital District State Appropriations. K.K. was supported by the OrionFarmos Research Foundation and the Academy of Finland (grant no. 125973).
}

\section{Author details}

'Department of Pathology, Haartman Institute, University of Helsinki, and Laboratory of Helsinki and Uusimaa University Hospital, Helsinki, Finland. ${ }^{2}$ Rinnekoti Foundation, Rehabilitation Home for Children, Espoo, Finland. ${ }^{3}$ Department of Pediatric Neurology, Helsinki University Central Hospital, Helsinki, Finland. ${ }^{4}$ Väestöliitto, The Family Federation of Finland, Department of Medical Genetics, Helsinki, Finland. ${ }^{5}$ Department of Pathology, VU University Medical Center, Amsterdam, The Netherlands. ${ }^{6}$ Public Health Genomics Unit, Department of Chronic Disease Prevention, National Institute for Health and Welfare, Helsinki, Finland. ${ }^{7}$ Institute for Molecular Medicine Finland FIMM, University Helsinki, Helsinki, Finland. ${ }^{8}$ Department of Clinical Genetics, Turku University Hospital and Department of Medical Biochemistry and Genetics, University of Turku, Turku, Finland. ' Department of Pediatrics, Satakunta Hospital District, Pori, Finland. ${ }^{10}$ Population Health Unit, Department of Health, Functional Capacity and Welfare, National Institute for Health and Welfare, P.O. Box 21 00014, Helsinki, Finland.

Received: 30 May 2011 Accepted: 5 September 2012 Published: 17 September 2012

\section{References}

1. Miller DT, Adam MP, Aradhya S, Biesecker LG, Brothman AR, Carter NP, Church DM, Crolla JA, Eichler EE, Epstein CJ, Faucett WA, Feuk L, Friedman JM, Hamosh A, Jackson L, Kaminsky EB, Kok K, Krantz ID, Kuhn RM, Lee C, Ostell JM, Rosenberg C, Scherer SW, Spinner NB, Stavropoulos DJ, Tepperberg JH, Thorland EC, Vermeesch JR, Waggoner DJ, Watson MS, Martin LC, Ledbetter DH: Consensus statement: chromosomal microarray is a first-tier clinical diagnostic test for individuals with developmental disabilities or congenital anomalies. Am J Hum Genet 2010, 86:749-764.

2. Siggberg L, Ala-Mello S, Jaakkola E, Kuusinen E, Schuit R, Kohlhase J, Bohm D, Ihnatius J, Knuutila S: Array CGH in molecular diagnosis of mental retardation - A study of 150 Finnish patients. Am J Med Genet A 2010, 152A:1398-1410.

3. Robinson WP: Mechanisms leading to uniparental disomy and their clinical consequences. BioEssays 2000, 22:52-459.

4. Liehr T: Cytogenetic contribution to uniparental disomy (UPD). Mol Cytogenet 2010, 3:8.

5. Kotzot D: Complex and segmental uniparental disomy updated. $J$ Med Genet 2008, 45:545-556.

6. Health: THL - National Institute for Health and Welfare. 2000. Accessed 30.8.2010, 2010, at http://www.terveys2000.fi/indexe.html.

7. Wang K, Li M, Hadley D, Liu R, Glessner J, Grant SF, Hakonarson H, Bucan M: PennCNV: An integrated hidden Markov model designed for highresolution copy number variation detection in whole-genome SNP genotyping data. Genome Res 2007, 17:1665-1674.

8. International HapMap Consortium: A haplotype map of the human genome. Nature 2005, 437:1299-1320.

9. lafrate AJ, Feuk L, Rivera MN, Listewnik ML, Donahoe PK, Qi Y, Sherer SW Lee C: Detection of large-scale variation in the human genome. Nat Genet 2004, 36:949-951.

10. Kristiansson K, Naukkarinen J, Peltonen L: Isolated populations and complex disease gene identification. Genome Biol 2008, 9:109.

11. Conlin LK, Thiel BD, Bonnemann CG, Medne L, Ernst LM, Zackai EH, Deardorff MA, Krantz ID, Hakonarson H, Spinner NB: Mechanisms of mosaicism, chimerism and uniparental disomy identified by single nucleotide polymorphism array analysis. Hum Mol Genet 2010, 19:1263-1275.

12. Engel $\mathrm{E}: \mathrm{A}$ fascination with chromosome rescue in uniparental disomy: Mendelian recessive outlaws and imprinting copyrights infringements. Eur J Hum Genet 2006, 14:1158-1169.

13. Bernardini L, Alesi V, Loddo S, Novelli A, Bottillo I, Battaglia A, Digilio MC, Zampino G, Ertel A, Fortina P, Surrey S, Dallapiccola B: High-resolution SNP arrays in mental retardation diagnostics: how much do we gain? Eur J Hum Genet 2010, 18:178-185.

14. Mannik K, Parkel S, Palta P, Zilina O, Puusepp H, Esko T, Magi R, Noukas M, Veidenberg A, Nelis M, Metspalu A, Remm M, Ounap K, Kurg A: A parallel SNP array study of genomic aberrations associated with mental retardation in patients and general population in Estonia. Eur J Med Genet 2011, 54:136-143.

15. Bruno DL, Ganesamoorthy D, Schoumans J, Bankier A, Coman D, Delatycki M, Gardner RJ, Hunter M, James PA, Kannu P, McGilivray G, 
Pachter N, Peters H, Rieubland C, Savarirayan R, Scheffer IE, Sheffield L, Tan T, White SM, Yeung A, Bowman Z, Ngo C, Choy KW, Cacheux V, Wong L, Amor DJ, Slater HR: Detection of cryptic pathogenic copy number variations and constitutional loss of heterozygosity using high resolution SNP microarray analysis in 117 patients referred for cytogenetic analysis and impact on clinical practice. J Med Genet 2009, 6:123-131.

16. McMullan DJ, Bonin M, Hehir-Kwa JY, de Vries BB, Dufke A, Rattenberry E, Steehouwer M, Moruz L, Pfundt R, de Leeuw N, Riess A, Altug-Teber O, Enders H, Singer S, Grasshof U, Walter M, Walker JM, Lamb CV, Davison EV, Bruetin L, Riess O, Veltman JA: Molecular karyotyping of patients with unexplained mental retardation by SNP arrays: a multicenter study. Hum Mutat 2009, 30:1082-1092.

17. Friedman J, Adam S, Arbour L, Armstrong L, Baross A, Birch P, Boerkoel C, Chan S, Chai D, Delaney AD, Flibotte S, Gibson WT, Langlois S, Lemyre E, Li HI, MacLeod P, Mathers J, Michaud JL, McGillivray BC, Patel MS, Qian H, Rouleau GA, Van Allen MI, Yong SL, Zahir FR, Eydoux P, Marra MA: Detection of pathogenic copy number variants in children with idiopathic intellectual disability using $500 \mathrm{~K} \mathrm{SNP}$ array genomic hybridization. BMC Genomics 2009, 10:526.

18. Behnecke A, Hinderhofer K, Bartsch O, Nümann A, Ipach ML, Damatova N, Haaf T, Dufke A, Riess O, Moog U: Intragenic deletions of IL1RAPL1: Report of two cases and review of the literature. Am J Med Genet A 2011, 155A:372-379.

19. Vissers LE, de Ligt J, Gilissen C, Janssen I, Steehouwer M, de Vries P, van Lier B, Arts P, Wieskamp N, del Rosario M, van Bon BW, Hoischen A, de Vries BB, Bruner HG, Veltman JA: A de novo paradigm for mental retardation. Nat Genet 2010, 42:1109-1112.

doi:10.1186/1471-2350-13-84

Cite this article as: Siggberg et al:: High-resolution SNP array analysis of patients with developmental disorder and normal array CGH results.

BMC Medical Genetics 2012 13:84.

\section{Submit your next manuscript to BioMed Central and take full advantage of:}

- Convenient online submission

- Thorough peer review

- No space constraints or color figure charges

- Immediate publication on acceptance

- Inclusion in PubMed, CAS, Scopus and Google Scholar

- Research which is freely available for redistribution 